\title{
Review of Almond (Prunus Dulcis) Shell Use to Remove Pollutants from Aquatic Environments
}

\author{
Ildar G. Shaikhiev ${ }^{1 \mathbb{D}}$, Natalia V. Kraysman ${ }^{2, * \mathbb{D}}$, Svetlana V. Sverguzova ${ }^{3 \mathbb{C}}$ \\ 1 Department of Engineering Ecology, Institute of Chemical Engineering and Technology, Kazan National Research \\ Technological University, Kazan, Russian Federation; ildars@inbox.ru (I.G.S.); \\ 2 Department of Foreign Languages for Professional Communication, Institute of Innovation Management, Kazan National \\ Research Technological University, Kazan, Russian Federation; n_kraysman@mail.ru (N.V.K.); \\ 3 Department of Industrial Ecology, Institute of Chemical Engineering and Technology, Belgo-rod State Technological \\ University named after V.G. Shukhov, Belgorod, Russian Federation; pe@ intbel.ru (S.V.S.); \\ * Correspondence: n_kraysman@mail.ru (I.G.S.);
}

Scopus Author ID 56114338900

Received: 21.02.2021; Revised: 15.03.2021; Accepted: 18.03.2021; Published: 1.04.2021

\begin{abstract}
We summarized the literature data on using ground almond (Prunus dulcis) green hull and shell as sorption materials to remove various metal ions, dyes, and some organic compounds from aqueous media. This paper provides brief information on the amount of waste generated from processing almonds, their chemical composition, and ways of reuse. It gives the adsorption processes parameters and the values of sorption parameters for the studied pollutants. It was shown that almond shells' sorption characteristics for various pollutants could be increased by chemical modification with various chemical reagents. It was determined that the Langmuir model more accurately describes the pollutants adsorption isotherms in most cases, and the kinetics of the process in all cases follows the pseudo-second-order model. It was shown that almond hulls and shells are a good precursor for activated carbons production.
\end{abstract}

Keywords: almond shells; metal ions; dyes; adsorption; modification.

(C) 2021 by the authors. This article is an open-access article distributed under the terms and conditions of the Creative Commons Attribution (CC BY) license (https://creativecommons.org/licenses/by/4.0/).

\section{Introduction}

Currently, the world scientific and industrial community is rapidly developing a new innovative environmental protection area - the use of lignocellulosic waste of agricultural production, as well as the components and waste of processing wood biomass of coniferous and deciduous trees as reagents to remove pollutants from water environments [1-10]. Ligno-, cellulose-, and tannin-containing wood processing wastes are of particular interest in removing pollutants of various origins from water bodies [11-15].

It was shown that crushed bark [16], sawdust [17], leaves [18] of trees are effective sorption materials to remove pollutants of various origins from natural and wastewater.

In the industrial processing of tree fruits, waste is also generated in the form of seeds [19], fruit rind [20], and nut-shells. The latter has been studied as sorption materials to remove metal ions, dyes, petroleum products, and other compounds from aqueous media. The number of papers on using tree fruit processing waste is so large that many materials are considered in the corresponding reviews. In particular, we summarized the data on the use of chestnut [21] and walnut [22] shells as a sorption material to remove pollutants from aqueous media. 
One of the domesticated tree species that is a source of nuts widely used by humans is the almond.

\section{Description of Trees, Volumes of Production, and Chemical Composition of Almond Shells}

Almond (Prunus dulcis) is a shrub or small tree, subgenus Almond (Amygdalus), genus Prunus. The shrub (less commonly a small tree) is 4-6m high, very branchy. There are two types of shoots: elongated vegetative and short generative. The leaves are petiolate, lanceolate, with a long-pointed tip.

The flowers are solitary, up to $2.5 \mathrm{~cm}$ in diameter, with white or light pink petals, numerous stamens, and a single pistil, and consist of a cup-shaped monosepalous calyx and a pink or red corolla. The flowers bloom before the leaves shoot.

The fruit is a dry velvety-downy oval monopyrenous drupe with a leathery green fleshy inedible green hull. The ripe, dry pericarp is easily separated from the shell. The shell has the same shape as the kernel itself, is covered with small dimples, sometimes with grooves, 2.5$3.5 \mathrm{~cm}$ long, weighing $1-5 \mathrm{~g}$ [23].

Almond production generates large amounts of by-products. While almonds' nutritional and commercial relevance is restricted to the kernel, almond by-products, constituted by hull, shell, and skin [24]. The heaviest material is the green hull, amounting on average to $52.0 \%$ of the fruit's total raw weight, while the shell and kernel (including the skin) account for about $33.0 \%$ and $15.0 \%$ of the total raw weight, respectively [24].

Almond is the raw material for the production of fatty almond oil and seeds. Almond seeds are cold or hot-pressed to produce oil that is used in the food, perfume, and pharmaceutical industries. It is used as a camphor solvent for injection, a basis for therapeutic and cosmetic ointments (it softens skin and has an anti-inflammatory effect), it is administered orally, especially for children, as a laxative, and in the form of emulsions as an enveloping and softening agent [23].

One of the largest almonds producers is the United States of America, with 1,872,500 tons of almonds produced in 2018. Other major producers of almonds are Spain (339,033 tons), Iran (139,029 tons), Morocco (117,270 tons), and (Turkey (100,000 tons). The total volume of global almond production in 2018 was 3,209,878 tons [25].

The latter accounts for 55-65\% (on average 60\%) of the almond weight. Accordingly, the number of almond shells alone generated only in 2018 on a global scale amounted to more than 1,900 thousand tons, creating certain problems to use them.

The almond hull is a green shell or covers the thin mesocarp, which forms 35.0-62.0\% of total almond of fresh weight $[24,26]$. Its weight and thickness differ considerably among species; in some of them, it is dry and thin and provides a small portion of the whole fruit, while other varieties have fleshy and thick hulls, providing a big proportion of the fruit weight [24, 27]. The hull characteristics condition the fruit removal from the tree. Apart from that, the features of hulls directly influence drying after the efficiency and harvest of hull removal [24, 27]. The nutritional composition of almond hulls depends not only on the almond variety to a great extent but also on agronomical management and environmental factors that contribute strongly to the final physico-chemical and phytochemical properties of the almond kernel and its by-products. Consequently, the sugar content in almond hulls ranges from 18.0 to $30.0 \%$, protein content varies from 2.1 to $8.8 \%$, and crude fiber ranges from 10.0 to $24.9 \%$. Acid detergent fiber differs from 20.6 to $35.2 \%$, neutral detergent fiber from 10.0 to $15.0 \%$, cellulose 
from 20.6 to $35.2 \%$, and crude lignin ranges from 7.5 to $15.6 \%$. Depending on the harvest method, ashes can differ from 7.0 to $8.3 \%$ but can be even higher than $9.0 \%$. In these cases, they are classified as "almond hulls and dirt" [24, 28].

Almond endocarp is known as a shell composed of compact arrangements of lignocellulosic sclereid cells. It is primarily composed of cellulose (ranging from 29.8 to 50.7 $\%$ ), hemicellulose (from 19.3 to $29.0 \%$ ), and lignin (from 20.4 to $50.7 \%$ ) [24, 29]. A shell's hardness is associated with the total amount of lignin formed during the nut development [24, 27], morphology, fiber content, and outer shell adherence [24, 29].

The composition of the dry shell of almond seeds $(\mathrm{g} / \mathrm{kg})$ is as follows [30]: dry matter971.2, organic matter-900.8, crude protein-103.4, ether extract-26.7, acid detergent fiber 303.5, neutral detergent fiber -619.8 , water-soluble carbohydrates -141.3 , ash -99.2 . The elemental composition of the organic component of almond seed shell:

$\mathrm{C}-44.80 \%, \mathrm{H}-7.10 \%, \mathrm{~N}-0.43 \%, \mathrm{~S}-<0.1 \%, \mathrm{O}-47.60 \%$ [31].

These chemical elements are present in cellulose, hemicellulose, lignin; the composition of almond hulls and shells also includes biologically active substances from phenolic acids (vanilla, caffeic, ferulic, etc.), flavonoids (catechin, kaempferol, quercetin, morin, etc.), sterols (stigmasterol, b-sitosterol) and triterpenoids (betullic, ursulic, oleanolic, maslinic acids and etc.) classes. A more detailed list of biologically active substances in the composition of almond by-products is given in the review [24].

The world literature provides information on the use of almond processing waste in various industries [32-43]. The composition of green hulls was studied, and the latter was proposed, in particular, as livestock feed [32]. The composition of the products of almond shell delignification by extraction was studied, and it was proposed to use lignins as bio-sourced phenolic resins [33]. The production of polyester-based biocomposites containing INZEA F2® biopolymer and almond shell powder was proposed [34]. Almond shells can also be used in the production of wood-particle panels [35], cardboard [36], and bio-oil [37]. The most widespread is the burning of almond processing products to produce energy and activated carbons [38, 39]. It is proposed to use almond shell waste as a new natural dye [40], a source of oligosaccharides and antioxidants [41, 42]. Almond shell extract can be used as a corrosion inhibitor [43].

The presence of biopolymers and biologically active substances in the composition of almond processing by-products, which have various functional groups in their composition, contribute to their use as sorption materials to remove pollutants from aqueous media. This review summarizes literature information on the use of almond shells as sorption materials to remove pollutants of various nature from wastewater and natural water.

\section{Use of Almond Processing By-products to Remove Heavy Metal Ions from Aqueous Media}

\subsection{Co(II) ions.}

Almond green hull was chemically treated and used for the adsorption ions of Co(II) from aqueous solutions. This new absorbent's efficiency was studied using batch adsorption technique under different experimental conditions such as sorbent amount, initial metal-ion concentration, contact time, adsorbent particle size, and chemical treatment. The maximum adsorption capacity of this new sorbent was found to be $45.5 \mathrm{mg} / \mathrm{g}$. The optimum dose of sorbent for maximum metal-ion adsorption was $0.25 \mathrm{~g}$ for $51.5 \mathrm{mg} / \mathrm{l}$ and $0.4 \mathrm{~g}$ for $110 \mathrm{mg} / \mathrm{l}$ 
solutions, respectively. Co (II) high removal efficiencies have occurred in the first $1 \mathrm{~min}$ of sorbent contact time. The Langmuir adsorption model corresponds to the experimental data appropriately well compared to the Freundlich model. Co (II) adsorption on the almond green hull was also observed to follow the pseudo-second-order kinetics [44].

\section{2. $C r(V I)$ ions.}

Adsorption of almond shell $\mathrm{Cr}^{6+}$ ions under static conditions at an initial concentration of $\mathrm{Cr}$ (VI), $10^{-3} \mathrm{~mol} / \mathrm{l} ; 0.5 \mathrm{~g}$ sorbent; $20 \mathrm{ml}$ of adsorption medium; temperature, $25 \pm 1{ }^{\circ} \mathrm{C}$ was examined. It was found that the maximum adsorption capacity of $3.40 \mathrm{mg} / \mathrm{g}$ is reached at $\mathrm{pH}=$ 3.2. Kinetic experiments revealed that the dilute chromium solutions reached equilibrium within $100 \mathrm{~min}$. It was defined that the adsorption isotherm is most accurately described by the Freundlich model [45].

At the same time, another study determined that the maximum sorption capacity of the almond shell for $\mathrm{Cr}^{6+}$ ions was $0.21 \mathrm{mg} / \mathrm{g}$. The adsorption was solution $\mathrm{pH}$-dependent, and the maximum adsorption was observed at solution $\mathrm{pH}=2.0$. Experimental data showed a good fit with the Freundlich isotherm model. The kinetics of the process are described by the pseudosecond-order equation [46].

The selected adsorbents (wool, almond shells, etc.) were used at concentrations ranging from 2 to $24 \mathrm{~g} / \mathrm{dm}^{3}$ in a batch adsorption technique at $30^{\circ} \mathrm{C}$. At $8 \mathrm{~g} / \mathrm{dm}^{3}$ of adsorbent, the removal of $\mathrm{Cr}^{6+}(100 \mathrm{ppm})$ was found to be between $68.7 \%$ for wool and $19.8 \%$ for almond shells. The maximum sorption capacity calculated from the Langmuir equation was $10.6 \mathrm{mg} / \mathrm{g}$ [47].

\section{3. $\mathrm{Cu}(\mathrm{II})$ ions.}

Much more publications are devoted to the study of $\mathrm{Cu}^{2+}$ ions adsorption by almond processing by-products. The information is given in Table 1 .

Table 1. Experiment conditions and metal ions adsorption characteristics of the native and modified watermelon rind.

\begin{tabular}{|c|c|c|c|c|}
\hline Metal ion & Experiment conditions & Adsorption characteristics & Note & Source \\
\hline \multirow[t]{6}{*}{$\mathrm{Cu}^{2+}$} & $\begin{array}{l}\mathrm{C}_{0}=10 \mathrm{mg} / \mathrm{dm}^{3}, \quad \text { DS }= \\
10 \mathrm{~g} / \mathrm{dm}^{3}, \mathrm{pH}=5 \text { and } \mathrm{t}= \\
120 \mathrm{~min}^{\circ} \mathrm{T}=25^{\circ} \mathrm{C} . \\
\mathrm{C}_{0}=5-50 \mathrm{mg} / \mathrm{dm}^{3}, \text { DS }= \\
10 \mathrm{~g} / \mathrm{dm}^{3}, \mathrm{pH}=5, \mathrm{t}=100 \mathrm{~min}, \\
\mathrm{~T}=25^{\circ} \mathrm{C}, 300 \mathrm{rpm}\end{array}$ & $\mathrm{A}=7.5 \mathrm{mg} / \mathrm{g}$ at $\mathrm{C}_{0}=10 \mathrm{mg} / \mathrm{dm}^{3}$ & $\begin{array}{l}\text { the Langmuir model, } \\
\text { pseudo-second-order } \\
\text { kinetics } \\
\text { the Langmuir model }\left(\mathrm{R}^{2}=\right. \\
0.980)\end{array}$ & [48] \\
\hline & $\begin{array}{l}\mathrm{C}_{0}=10-70 \mathrm{ppm}, \mathrm{DS}=4 \mathrm{~g} / \mathrm{dm} 3 \\
\mathrm{pH}=7, \mathrm{t}=60 \mathrm{~min}, \mathrm{~T}=26-55^{\circ} \mathrm{C}\end{array}$ & $\begin{array}{l}\text { The removal rate is } 74.9 \% \text { at } \\
\mathrm{C}_{0}=10 \mathrm{ppm}, 45.6 \% \text { at } \mathrm{C}_{0}= \\
70 \mathrm{ppm}\end{array}$ & $\begin{array}{l}\text { pseudo-second-order } \\
\text { model }\end{array}$ & {$[50]$} \\
\hline & $\begin{array}{l}\mathrm{C}_{0}=0.005-0.05 \mathrm{mmol} / \mathrm{ml}, \mathrm{pH} \\
=2-9, \mathrm{t}=10-240 \mathrm{~min}, \text { and } \mathrm{DS}= \\
0.1-1.0 \mathrm{~g} / \mathrm{dm}^{3}\end{array}$ & $\begin{array}{l}\mathrm{A}=3.62 \mathrm{mg} / \mathrm{g} \mathrm{Cu}(\mathrm{II}) \text { ions } \\
\text { removal rate is } 75.0 \% \text { at } \mathrm{C}_{\mathrm{o}}= \\
10^{-3} \mathrm{~mol} / \mathrm{dm}^{3}, \mathrm{pH}=6\end{array}$ & $\begin{array}{l}\text { the Langmuir model }\left(\mathrm{R}^{2}=\right. \\
0.980)\end{array}$ & [51] \\
\hline & $\begin{array}{l}\mathrm{C}_{0}=50 \mathrm{mg} / \mathrm{dm}^{3}, \quad \mathrm{DS}=0.1- \\
1.0 \mathrm{~g} / \mathrm{dm}^{3}, \mathrm{pH}=5, \mathrm{t}=60 \mathrm{~min}, \mathrm{~T} \\
=20^{\circ} \mathrm{C}, 125 \mathrm{rpm}\end{array}$ & $\begin{array}{l}\mathrm{A}=4.70 \mathrm{mg} / \mathrm{g} \text { at } \mathrm{DS}= \\
0.5 \mathrm{mg} / \mathrm{dm}^{3}, \mathrm{Cu}(\mathrm{II}) \text { ion } \\
\text { removal rate is } 64 \% \text { at } \mathrm{DS}= \\
1 \mathrm{~g} / \mathrm{dm}^{3}\end{array}$ & $\begin{array}{l}\text { the Langmuir model }\left(\mathrm{R}^{2}=\right. \\
0.980) \text {, pseudo-second- } \\
\text { order kinetics }\end{array}$ & [52] \\
\hline & $\begin{array}{l}\text { Native and modified almond } \\
\text { shell. } \mathrm{C}_{0}=25-200 \mathrm{mg} / \mathrm{dm}^{3}, \mathrm{DS} \\
=4 \mathrm{~g} / \mathrm{dm}^{3}, \mathrm{pH}=1-6, \mathrm{t}=100 \mathrm{~min}, \\
\mathrm{~T}=30^{\circ} \mathrm{C}, 100 \mathrm{rpm}\end{array}$ & $\begin{array}{l}\mathrm{A}=18.71 \text { and } 28.27 \mathrm{mg} / \mathrm{g} \text { for } \\
\text { native and modified almond } \\
\text { shell }\end{array}$ & $\begin{array}{l}\text { AS: Temkin > Freundlich > } \\
\text { Toth > Redlich-Peterson > } \\
\text { Langmuir. pseudo-second- } \\
\text { order kinetics }\left(\mathrm{R}^{2}=0.997\right)\end{array}$ & $\begin{array}{l}{[53],} \\
{[54]}\end{array}$ \\
\hline & $\begin{array}{l}\text { Dynamic conditions. } \mathrm{C}_{0}= \\
15 \mathrm{mg} / \mathrm{dm}^{3} \text {, the flow rate is } 10- \\
20 \mathrm{~cm}^{3} / \mathrm{min} \text {, the layer height is } \\
7 \mathrm{~cm} .\end{array}$ & $\begin{array}{l}\mathrm{A}=12.88 \mathrm{mg} / \mathrm{g} \text { at a flow rate } \\
\text { of } 20 \mathrm{~cm}^{3} / \mathrm{min}\end{array}$ & The Thomas model & [55] \\
\hline
\end{tabular}




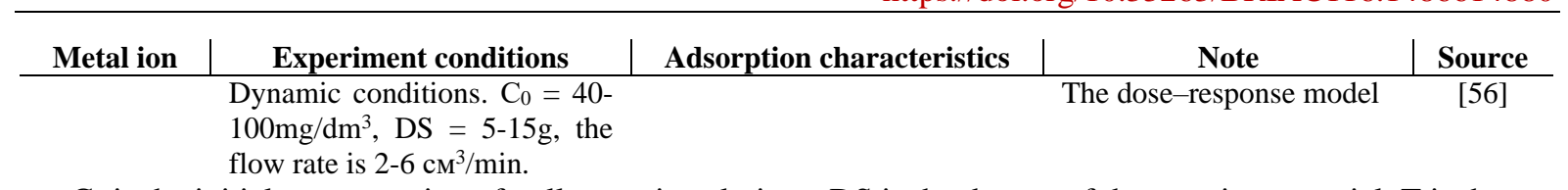

$\mathrm{C}_{0}$ is the initial concentration of pollutants in solutions, DS is the dosage of the sorption material, $\mathrm{T}$ is the experiment temperature, $t$ is the adsorption time, and $A_{\max }$ is the maximum adsorption capacity.

\section{4. $\mathrm{Hg}(I I)$ ions.}

The adsorption of $\mathrm{Hg}^{2+}$ ions by native and activated almond shell (RAS and AAS, respectively) was studied under the following conditions: the initial mercury ion concentration was from 25 to $100 \mathrm{mg} / \mathrm{dm}^{3}$ at $\mathrm{pH}=5$ and a temperature of $298 \mathrm{~K}$. The Langmuir monolayer capacity $\left(\mathrm{A}_{\max }\right)$ has values of 3.77 and $37.17 \mathrm{mg} / \mathrm{g}$ for RAS and AAS, respectively. It was determined that the adsorption isotherms are described by the Langmuir model and the kinetics of the process by the pseudo-second-order model [57]. Similar data were obtained in [57], but it was determined that the maximum almond shell sorption capacity for $\mathrm{Hg}^{2+}$ ions, determined by the Langmuir equation, was $135.1 \mathrm{mg} / \mathrm{g}$. It was found that the adsorption process is endothermic and spontaneous [58].

\section{5. $\mathrm{Pb}(I I)$ ions.}

Almond shell was studied as a sorption material to remove $\mathrm{Pb}^{2+}$ ions from simulated solutions with varying process parameters. It was determined that the almond shell maximum sorption capacity for this metal was $8.08 \mathrm{mg} / \mathrm{g}$ after 2 hours of contact at $\mathrm{pH}=7$. The adsorption data are in good agreement with the Langmuir isotherm model, and it was concluded that adsorption, chelation, and ion exchange are the main adsorption mechanisms for $\mathrm{Pb}^{2+}$ ion binding by the sorbent under study [59].

Almond green hull magnetized using the $\mathrm{Fe}_{3} \mathrm{O}_{4}$ magnetite was used to remove $\mathrm{Pb}^{2+}$ ions. The maximum removal rate was reached at $\mathrm{pH}=9$ and an absorption dose of $5 \mathrm{~g} / \mathrm{dm}^{3}$. It was found that the $\mathrm{Pb}^{2+}$ ions removal rate decreased with an increase in the initial concentration of ions, an increase in the contact time, and the mixing rate. It was found that the removal degree was $91.34 \%$ at the initial concentration of $\mathrm{Pb}^{2+}$ ions $=10 \mathrm{mg} / \mathrm{dm}^{3}, \mathrm{pH}=9$, and the dosage of the sorption material $=2 \mathrm{~g} / \mathrm{dm}^{3}$. The adsorption isotherms correspond to the Langmuir model [60]. It was also found that a simulated solution containing initially $\mathrm{Pb}^{2+}$ ions at a concentration of $25 \mathrm{mg} / \mathrm{dm}^{3}$ after treatment with almond shell at a dosage of $10 \mathrm{~g} / \mathrm{dm}^{3}$ had some toxic effect on duckweed (Lemna minor) and tomato sprouts (Lycopersicum esculentum mill) [61].

\section{6. $\mathrm{Zn}(I I)$ ions.}

The adsorption of $\mathrm{Zn}^{2+}$ ions with a modified $1.86 \%$ solution of $\mathrm{H}_{2} \mathrm{SO}_{4}$ of almond shells was studied. It was found that the maximum sorption capacity was $5.54 \mathrm{mg} / \mathrm{g}$, and the adsorption isotherm is more accurately described $\left(\mathrm{R}^{2}=0.977\right)$ by the Freundlich model [62].

As it appears from the data in Table 1, all studies were conducted by the authors under different conditions, which does not allow us to compare the results obtained. The results of experiments conducted under similar conditions are much more effective. In the world literature, several articles are on the study of the adsorption of various ions by almond processing by-products.

In particular, the effect of various parameters was studied on $\mathrm{Cd}^{2+}$ and $\mathrm{Pb}^{2+}$ ions removal from simulated solutions containing $10 \mathrm{mg} / \mathrm{dm}^{3}$ of the above metals with alkali-treated almond shells. It was found that in both cases, the highest sorption capacity was at $\mathrm{pH}=5$. The 
suggested dosage of almond shells for adsorption of $\mathrm{Cd}^{2+}$ and $\mathrm{Pb}^{2+}$ is $1-3 \mathrm{~g} / \mathrm{dm}^{3}$. The amounts of $\mathrm{A}_{\max }$ in the Langmuir model for adsorption of $\mathrm{Cd}^{2+}$ and $\mathrm{Pb}^{2+}$ were 7.19 and $8.13 \mathrm{mg} / \mathrm{g}$, respectively. The Langmuir model more accurately describes the adsorption isotherms in the case of the removal of these ions. The values of $\Delta \mathrm{G}$ for adsorption of $\mathrm{Pb}^{2+}$ and $\mathrm{Cd}^{2+}$ were -33.5 and $-25.5 \mathrm{KJ} / \mathrm{mol}$, respectively. The negative value for Gibbs free energy shows that the adsorption process of $\mathrm{Pb}^{2+}$ and $\mathrm{Cd}^{2+}$ on the alkali-modified almond shell is spontaneous [63].

The adsorption capacity of almond shells (AS) for $\mathrm{Pb}^{2+}$ and $\mathrm{Cd}^{2+}$ ions was studied at $\mathrm{pH}$ $=5$ in $\mathrm{NaNO}_{3}$ and $\mathrm{NaCl}$ solutions in the initial concentrations range of $0.05-0.5 \mathrm{~mol} / \mathrm{dm}^{3}$ and a temperature of $26-60^{\circ} \mathrm{C}$. The Langmuir equation-based maximum sorption capacity values for $\mathrm{Pb}^{2+}$ and $\mathrm{Cd}^{2+}$ ions were 5.9 and $7.0 \mathrm{mg} / \mathrm{g}$, respectively. The adsorption isotherms in both cases are well described by the Sips and Langmuir model [64].

The adsorption of $\mathrm{Ni}^{2+}, \mathrm{Cd}^{2+}$, and $\mathrm{Pb}^{2+}$ ions by almond shells from aqueous solutions was studied. The negative values of free change $(\Delta \mathrm{G})$ indicate the spontaneous nature of $\mathrm{Ni}^{2+}, \mathrm{Cd}^{2+}$, and $\mathrm{Pb}^{2+}$ ions adsorption by almond shells, and the positive values of the enthalpy change $(\Delta \mathrm{H})$ prove the endothermic nature of adsorption. The best correlation coefficients were obtained for the pseudo-second-order kinetic model. Ion exchange is probably one of the main adsorption mechanisms to bind divalent metal ions to hazelnut and almond shells. The adsorbent selectivity order is as follows: $\mathrm{Pb}^{2+}(5.43 \mathrm{mg} / \mathrm{g})>\mathrm{Cd}^{2+}(3.18 \mathrm{mg} / \mathrm{g})>\mathrm{Ni}^{2+}(3.11 \mathrm{mg} / \mathrm{g})$ at the solution temperature of $298 \mathrm{~K}$ [65].

\section{7. $\mathrm{CN}$ - ions.}

Bioadsorption of cyanide by the almond shell in the batch reactor has been carried out. The optimum bioadsorbent dose is $20 \mathrm{~g} / \mathrm{l}$ for an optimum agitation time of 90 minutes. The effectiveness of cyanide removal decreased with an increased initial concentration of cyanide. Maximum specific uptake obtained from Langmuir isotherm is found to be $32.05 \mathrm{mg} / \mathrm{g}$ at $\mathrm{pH}$ $=7$. The experimental data have been analyzed using the Freundlich $\left(\mathrm{R}^{2}=0.995\right)$, Langmuir $\left(\mathrm{R}^{2}=0.946\right)$ and Temkin $\left(\mathrm{R}^{2}=0.919\right)$ isotherm models. These models are well represented by indicating favorable isotherm. Adsorption of cyanide onto almond shell obeyed the pseudosecond-order rate equation [66-68].

\section{Use of Almond Processing By-products to Remove Dyes from Aqueous Media}

Waste from the processing of agricultural raw materials and components of wood biomass has widely been studied as sorption materials for removing dyes from aqueous media [69-73].

A series of studies were carried out of Methyl orange dye removal by almond shells. It was found that the optimum set of parameters was obtained as the reaction time of $80 \mathrm{~min}$, initial dye concentration of $100 \mathrm{mg} / 1 \mathrm{l}, \mathrm{pH}=3$, and temperature of $20^{\circ} \mathrm{C}$. The equilibrium data pointed out an excellent fit to the Langmuir isotherm model with a maximum monolayer adsorption capacity of ` $41.34 \mathrm{mg} / \mathrm{g}$. The standard Gibbs free energy $(-6.74 \mathrm{~kJ} / \mathrm{mol})$ change was also calculated to define the biosorption process's nature. The $\Delta \mathrm{G}^{\circ}$ values obtained are within the ranges of -20 and $0 \mathrm{~kJ} / \mathrm{mol}$, confirming that physical biosorption was the dominating mechanism. It was found that the pseudo-second-order was the most relevant to describe the adsorption behavior [74-76]. The treatment of almond skin with an alkaline solution as well as with salt solution decreased the sorption ability for Methyl orange, whereas the acidic treatment increased the sorption ability markedly for the anionic dye [77]. 
Violet B azo dye adsorption by various agricultural raw materials processing by-products (almond shell, pistachio shell, walnut shell, Tea waste, and orange peel) was studied. The results showed that the adsorption efficiency of violet $\mathrm{B}$ by cellulose agricultural waste materials is as follows: almond shell > orange peel > pistachio shell > tea waste $>$ walnut shell. It was found that the almond shell maximum sorption capacity for the above dye was $96.0 \mathrm{mg} / \mathrm{g}$ [78]. In all cases, the adsorption isotherms were described more accurately by the Langmuir model. The kinetics of the process follow the pseudo-second-order model [78].

The magnetite-impregnated almond shell (MIAS) and untreated almond shell (UAS) were used as adsorbents for the removal of Methyl violet 2B dye from an aqueous solution. The pseudo-second-order represents the kinetic adsorption of dye on-to both adsorbents. Isotherm which was best fitted to Langmuir adsorption isotherm model. The monolayer Langmuir adsorption capacities of UAS and MIAS were 29.4 and $33.0 \mathrm{mg} / \mathrm{g}$, respectively. The thermodynamic parameters, including $\Delta \mathrm{S}, \Delta \mathrm{H}$, and $\Delta \mathrm{G}$, indicated that the adsorption of Methyl violet $2 \mathrm{~B}$ dye on-to both adsorbents were spontaneous, feasible, and endothermic [79].

Comparative batch adsorption of Crystal Violet (CV) dye using the almond shell as an adsorbent in untreated form and activated with sodium hydroxide was carried out in search of optimum adsorption conditions. The operation parameters investigated were contact time (10 to $80 \mathrm{~min})$, temperature $\left(20-50^{\circ} \mathrm{C}\right)$, initial dye concentrations $(40-240 \mathrm{mg} / \mathrm{L})$, and $\mathrm{pH},(2-12)$. Maximum adsorption was observed in a basic medium. The adsorption equilibrium of $\mathrm{CV}$ was attained very rapidly after $40 \mathrm{~min}$ of contact time. Determined that the kinetic adsorption data were best fitted to the Langmuir isotherm model and best fitted to a pseudo-second-order model. The performance of both adsorbents to adsorb CV was also compared. It was found that the adsorption capacity of almond shell activated by base was higher [80].

Presents an alternative methodology for the removal of a dye Rhodamine $6 \mathrm{G}$ from aqueous solutions by using the almond shell in a batch biosorption technique. The biosorption characteristics of dye onto almond shell were examined with respect to the changes in initial $\mathrm{pH}$ of dye solutions, initial dye concentration, adsorbent concentration, contact time, temperature etc. The monolayer biosorption capacity of AS was found to be $32.6 \mathrm{mg} / \mathrm{g}$ by using Langmuir model equations. Experimental data showed a good fit with both the Langmuir and Freundlich isotherm models. The biosorption kinetics was followed by a pseudo-second-order model for all investigated initial Rhodamine $6 \mathrm{G}$ concentrations. Thermodynamic parameters including the Gibbs free energy $\left(\Delta \mathrm{G}^{\mathrm{o}}=-0.92\right.$ to $-4.45 \mathrm{~kJ} / \mathrm{mol}$ with an increase in temperature from 0 to $\left.40{ }^{\circ} \mathrm{C}\right)$, enthalpy $\left(\Delta \mathrm{H}^{\mathrm{o}}=24.14 \mathrm{~kJ} / \mathrm{mol}\right)$, and entropy $\left(\Delta \mathrm{S}^{\mathrm{o}}=91.43 \mathrm{~J} / \mathrm{mol} \cdot \mathrm{K}\right)$ changes indicated that the biosorption was feasible, spontaneous and endothermic [81].

Also, the use of almond shell has been investigated to remove Rhodamine B from aqueous solutions. The results showed that the removal efficiency increased by increasing contact time, adsorbent dosage, and initial dye concentration. In addition, the adsorption was dependant to-on solution $\mathrm{pH}$, and the maximum adsorption $(33.22 \mathrm{mg} / \mathrm{g})$ was observed at a solution $\mathrm{pH}=2.0$. Freundlich equation fits the experimental data better than the Langmuir and Temkin equations do [82].

The adsorption of Direct Red 80 dye from aqueous solution on almond shells. The effect of shell-type (internal, external, and mixture shells), $\mathrm{pH}$, and initial dye concentration was considered to evaluate the sorption capacity. Initial dye concentration was varied from 50 to $150 \mathrm{mg} / \mathrm{dm}^{3}$. The maximum adsorption capacity of different almond shells $(20.5,19.96$ and $16.4 \mathrm{mg} / \mathrm{g}$ for mixture, external and internal shells) was obtained at $\mathrm{pH}=2$. It was determined 
that the adsorption process by mixture type of almond shells follows the Langmuir non-linear isotherm, and the kinetics of the process follows the pseudo-second-order model [83].

The usage of the almond shell in the removal of Malachite green dye from aqueous solutions was evaluated with reference to various experimental parameters, including contact time, initial malachite green concentration, temperature, adsorbent concentration, etc. The monolayer adsorption capacity of the almond shell was found to be $29.0 \mathrm{mg} / \mathrm{g}$ at dye concentration $100 \mathrm{mg} / \mathrm{dm}^{3}$, almond shell $-10 \mathrm{~g} / \mathrm{dm}^{3}$, contact time $-1 \mathrm{~h}$. The adsorption kinetics of malachite green fitted well with the pseudo-second-order kinetic model. Thermodynamic parameters: $\Delta \mathrm{G}^{\mathrm{o}}=-1.12$ to $-4.51 \mathrm{~kJ} / \mathrm{mol}$ with an increase in temperature from 0 to $40{ }^{\circ} \mathrm{C}, \Delta \mathrm{H}^{\mathrm{o}}$ $=21.67 \mathrm{~kJ} / \mathrm{mol}, \Delta \mathrm{S}^{\mathrm{o}}=83.47 \mathrm{~J} / \mathrm{mol} \cdot \mathrm{K}$ indicated that the biosorption was feasible, spontaneous, and endothermic [84].

The performance and efficiency of an almond shell as adsorbent for the removal and recovery of Acid Blue 129 dye from model wastewater were evaluated. More than 98\% removal efficiency was obtained within $14 \mathrm{~min}$ at an adsorbent dose of $16 \mathrm{~g} / \mathrm{dm}^{3}$ for an initial dye concentration of dye $40 \mathrm{mg} / \mathrm{dm}^{3}$ at $\mathrm{pH}=2$. It was found that adsorption well with the Langmuir $\left(\mathrm{A}_{\max }=11.95 \mathrm{mg} / \mathrm{g}\right)$ and Temkin isotherm model [85].

\section{Use of Almond Processing By-products to Remove Various Organic Compounds from Aqueous Media}

The world literature describes the removal of various organic compounds from aqueous media by agricultural raw materials processing by-products. The information is given in the review articles $[86,87]$. There is also information about the use of almond processing byproducts as sorption materials for various organic pollutants.

Various agricultural wastes generated in Libya, including almond shells, were investigated to remove phenol at concentrations of 1-1,000ppm from simulated solutions. It was found that at an initial phenol concentration of $100 \mathrm{ppm}$, the extraction efficiency of the latter is $87 \%$ at a dosage of the almond shell of $20 \mathrm{~g} / \mathrm{dm}^{3}$. The results showed that the equilibrium data for the phenol-almond shell systems fitted the Freundlich model best within the concentration range studied, especially the concentrations below $100 \mathrm{ppm}$ [88].

The adsorption of Bisphenol A (4,4'-(propane-2,2-diyl)diphenol) by native and formaldehyde-treated almond shells was studied. At an initial concentration of Bisphenol A of $1 \mathrm{mg} / \mathrm{dm}^{3}$, the latter's removal rate was $95 \%$ and $87 \%$ for modified and native almond shells. It was found that the constructed adsorption isotherms are well described by the Freundlich model [89].

The adsorption of 2 polycyclic aromatic hydrocarbons, benzo(a)piren and benzo (ghi)perilen were studied using almond shells. Isotherms of benzo(ghi)perilen adsorption by almond shells were obtained, which showed that the maximum sorption capacity was $67.57 \mathrm{mg} / \mathrm{g}$. The adsorption isotherm is described by the Langmuir model and the kinetics of the process by the pseudo-second-order model [90].

The adsorption of pentachlorophenol on almond shells was also studied. It was determined that pentachlorophenol removal efficiency was $93 \%$ after 24 hours of the process at an initial concentration of the latter of $100 \mathrm{~g} / \mathrm{dm}^{3}$. The sorption capacity of almond shells for this reagent was $5 \mathrm{mg} / \mathrm{g}$ [91]. Under dynamic conditions, with an initial concentration of pentachlorophenol of $10 \mathrm{mg} / \mathrm{dm}^{3}$ and an almond shell content of $10 \mathrm{~g}$ in the column at a solution flow rate of $4 \mathrm{~cm}^{3} / \mathrm{min}$, the efficiency of the pollutant removal was over $99 \%$ [92]. 
The removal of $17 \beta$-estradiol from native and formaldehyde-modified $0.1-0.15 \mathrm{~mm}$ almond shells was studied. The experiments were conducted at $\mathrm{pH}=6.80$, adsorbent mass$20 \mathrm{~g} / \mathrm{dm}^{3}$, concentration of $17 \beta$-estradiol $=1.0 \mathrm{mg} / \mathrm{dm}^{3}, 25^{\circ} \mathrm{C}$, contact time $-48 \mathrm{~h}$. The percentage of adsorption was found to be 88 and $90 \%$ for the almond shells treated with formaldehyde or washed with hot water [93].

The adsorption of azoimide by almond shells was studied. It was found that the maximum sorption capacity for this substance, calculated by the Langmuir equation, was $44.6 \mathrm{mg} / \mathrm{g}$, and the Redlich-Peterson model most accurately described the isotherm itself. It was found that the kinetics of the process follows the pseudo-second-order equation. Thermodynamic parameters: $\Delta \mathrm{G}^{0}=-18.71$ to $-20.57 \mathrm{~kJ} / \mathrm{mol}$ with an increase in temperature from 293 to $313 \mathrm{~K}, \Delta \mathrm{H}^{\mathrm{o}}=8.52 \mathrm{~kJ} / \mathrm{mol}, \Delta \mathrm{S}^{\circ}=93 \mathrm{~J} / \mathrm{mol} \cdot \mathrm{K}$ indicated that the biosorption was spontaneous and endothermic [94].

\section{Production of Activated Carbons from Almond Processing By-products.}

Another area of almond processing by-products uses the production of activated carbons. In particular, activated carbons are reported to be produced by carbonizing almond shells at $400^{\circ} \mathrm{C}$ for 1 hour in $\mathrm{N}_{2}$ atmosphere and then activated at $700^{\circ} \mathrm{C}$ and $800^{\circ} \mathrm{C}$, in a $\mathrm{CO}_{2}$ constant flow of $85 \mathrm{~cm}^{3} / \mathrm{sm}^{3}$, during $1,2,3,5$, and $7 \mathrm{hrs,} \mathrm{in} \mathrm{order} \mathrm{to} \mathrm{get} \mathrm{burn-off} \mathrm{within} \mathrm{the} \mathrm{range} \mathrm{of} 12$ to $70 \mathrm{wt} . \%$. The utilized method has fabricated activated carbons with apparent BET surface areas and micropore volume as high as $1138 \mathrm{~m}^{2} / \mathrm{g}$ and $0.49 \mathrm{~cm}^{3} / \mathrm{g}$, consistently. The activated carbons produced have essentially primary micropores and only a small volume of wider micropores [95].

A series of phosphoric-acid activated carbons were produced from almond shells using six different activation or activation/oxidation methods. The carbons were compared to each other and two commercial carbons to ascertain the relative value of the carbons in terms of surface area, yield, attrition, organic uptake, surface functional groups, and metal and the estimated cost of production. Of the six methods investigated, the method that produced the best overall performing almond shell carbon and least expensive carbon in reference to production cost was the «Air-Activation» method. This method involved the simultaneous activation and oxidation of almond shells under an air atmosphere [96]. It is pointed out that the yield of activated carbon with this method was $34 \%$, and the surface area was $1,283 \mathrm{~m}^{2} / \mathrm{g}$, while in industrial samples of Norit RO 3515 and Calgon Filtrasorb 400 coals were 796 and $952 \mathrm{~m}^{2} / \mathrm{g}$, respectively. It was determined that the obtained activated carbon samples have a sorption capacity of $0.95 \mathrm{mmoles} / \mathrm{g}$ for $\mathrm{Cu}^{2+}$ ions and the Norit RO 3515 sample has a sorption capacity of $0.2 \mathrm{mmoles} / \mathrm{g}$ [96].

The obtained samples of activated carbons were studied as sorbents of such metal ions as $\mathrm{Ag}^{+}(59.52 \mathrm{mg} / \mathrm{g}$ at $308 \mathrm{~K})$ [97], $\mathrm{Cd}^{2+}$ [98], $\mathrm{Cr}^{6+}(190.3 \mathrm{mg} / \mathrm{g}$ at $323 \mathrm{~K})$ [99], (10.12mg/g from green hull) [100].

Adsorption of $\mathrm{Cu}^{2+}, \mathrm{Zn}^{2+}, \mathrm{Pb}^{2+}$, and $\mathrm{Cd}^{2+}$ ions that exist in industrial wastewater onto the carbon produced from nut-shells of hazelnut, pistachio, walnut, almond, and apricot stone has been investigated. The agricultural shells or stones used were ground, sieved to a defined size range, and carbonized in an oven. The time and temperature of heating were optimized at 15 min and $800^{\circ} \mathrm{C}$, respectively, to reach maximum removal efficiency. The removal efficiency was optimized regarding the initial $\mathrm{pH}$, flow rate, and dose of the adsorbent. The maximum removal occurred at $\mathrm{pH}=6-10$, a flow rate of $3 \mathrm{sm}^{3} / \mathrm{min}$, and $0.1 \mathrm{~g}$ of the adsorbent. Removal of $\mathrm{Cu}, \mathrm{Zn}, \mathrm{Cd}$, and $\mathrm{Pb}$ from synthetic wastewater using walnut, hazelnut, pistachio, almond 
shell, and apricot stone carbon (Figure 2) [101]. It was determined that the degree of removal of $\mathrm{Cu}$ (II) ions by the named carbon is $83.0-99.8 \%, \mathrm{Cd}$ (II) ions - 33.8 to $90.5 \%, \mathrm{~Pb}$ (II) ions 52.7 to $96.9 \%$ and $\mathrm{Zn}$ (II) ions - 58.8-71.0\% [101].

Besides, the activated carbons from almond processing by-products were used as sorbents of various dyes, such as Acridine orange (the maximum adsorption capacity was found to be $909.1 \mathrm{mg} / \mathrm{g}$ at $313 \mathrm{~K}$ [102], Methylene blue $(51.8 \mathrm{mg} / \mathrm{g})$ [103]. Removal of nitrogencontaining compounds such as picoline $(288.57 \mathrm{mg} / \mathrm{g})$ [104], 2,4,6-trinitrophenol $(74.0 \mathrm{mg} / \mathrm{g}$ at $\left.25^{\circ} \mathrm{C}\right)$ [105], the antibiotic amoxicillin $(2.5 \mathrm{mg} / \mathrm{g}$ at $303 \mathrm{~K})$ [106] and other compounds of organic and inorganic origin was also studied.

\section{Conclusions}

In this review, we summarized the literature data on the use of ground almond (Prunus dulcis) processing waste as sorption materials to remove various metal ions $\left(\mathrm{Co}^{2+}, \mathrm{Cr}^{6+}, \mathrm{Cu}^{2+}\right.$, $\mathrm{Hg}^{2+}, \mathrm{Pb}^{2+}, \mathrm{Zn}^{2+}$ ) and $\mathrm{CN}^{-}$, dyes and some organic compounds from aqueous media. This paper provides brief information on the amount of waste generated from processing almonds, its their chemical composition, and ways of reuse. It gives the adsorption processes parameters and the values of sorption parameters for the studied pollutants. It was shown that almond processing waste sorption characteristics for various pollutants could be increased by chemical modification with various reagents. It was determined that the Langmuir model more accurately describes the pollutants adsorption isotherms in most cases, and the kinetics of the process in all cases follows the pseudo-second-order model. It was shown that almond hulls and shells are good precursors to produce activated carbons.

\section{Funding}

This research received no external funding.

\section{Acknowledgments}

This research has no acknowledgment.

\section{Conflicts of Interest}

The authors declare no conflict of interest.

\section{References}

1. Yeow, P.K.; Wong, S.W; Hadibarata, T. Removal of azo and anthraquinone dye by plant biomass as adsorbent - a review. Biointerface Res. ApChem. 2021, 11, 8218-8232, https://doi.org/10.33263/BRIAC111.82188232.

2. Liu, Q.; Li, Y.; Chen, H.; Lu, J.: Yu, G.; Möslang, M.; Zhou. Y. Superior adsorption capacity of functionalised straw adsorbent for dyes and heavy-metal ions. J. Hazard. Mater. 2020, 382, 121040, https://doi.org/10.1016/j.jhazmat.2019.121040.

3. Chong S.N.; Hadibarata T. Adsorption of phenol red and remazol brilliant blue R by coconut shells (Cocos nucifera) and ambarella peels (Spondias dulcis). Biointerface Res. ApChem. 2021, 11, 8564-8576, https://doi.org/10.33263/BRIAC111.85648576.

4. Shaikhiev, I.G; Sverguzova, S.V.; Galimova, R.Z.: Grechina, A.S. Using wastes of buckwheat processing as sorption materials for the removal of pollutants from aqueous media: A review. IOP Conf. Series: Mater. Science Eng. 2020, 945, 012044, 1-11, https://doi.org/10.1088/1757-899X/945/1/012044. 
5. Shaikh, T.M.A. Adsorption of $\mathrm{Pb}(\mathrm{II})$ from wastewater by natural and synthetic adsorbents. Biointerface Res. ApChem. 2020, 5, 6522-6539, https://doi.org/10.33263/BRIAC105.65226539.

6. Chakraborty, R.; Asthana, A.; Singh, A.K.; Jain, B.; Susan, A.BH. Adsorption of heavy metal ions by various low-cost adsorbents: a review. Int. J. Environ. Analyt. Chem. 2020, 1-38, https://doi.org/10.1080/03067319.2020.1722811.

7. Kanthasamy, S.; Hadibarata, T.; Hidayat, T.; Alamri, S.A.; Al-Ghamdi, A.A. Adsorption of azo and anthraquinone dye by using watermelon peel powder and corn peel powder: equilibrium and kinetic studies. Biointerface Res. ApChem. 2020, 1, 4706-4713, https://doi.org/10.33263/BRIAC101.706713.

8. Joseph, L.; Jun, B.; Flora, J.R.V.; Park, C.M..; Yoon, Y. Removal of heavy metals from water sources in the developing world using low-cost materials: a review. Chemosphere. 2019, 229, 142-159, https://doi.org/10.1016/j.chemosphere.2019.04.198.

9. Zhou Y.; Lu, J.; Zhou, Y.; Liu, Y. Recent advances for dyes removal using novel adsorbents: a review. Environ. Pollut. 2019, 252A, 352-36, https://doi.org/10.1016/j.envpol.2019.05.072.

10. Sverguzova, S.V.; Shaikhiev, I.G.; Hunade, L. Study of modified peanut peel sorption properties relative to Fe(III) ions. IOP Conf. Series: Earth Environ. Sci. 2020, 459, 042064, 1-6, https://doi.org/10.1088/17551315/459/4/042064.

11. Kovacova, Z.; Demcak, S.; Balintova, M.; Pla, C.; Zinicovscaia, I. Influence of wooden sawdust treatments on $\mathrm{Cu}(\mathrm{II})$ and $\mathrm{Zn}(\mathrm{II})$ removal from water. Materials. 2020, 13, 3575, 1-19, https://doi.org/10.3390/ma13163575.

12. Mashkoor, F.; Nasar, A. Magnetized Tectona grandis sawdust as a novel adsorbent: preparation, characterization, and utilization for the removal of methylene blue from aqueous solution. Cellulose. 2020, 27, 2613-2635, https://doi.org/10.1007/s10570-019-02918-8.

13. Zadeh, B.S.; Esmaeili, H.; Foroutan, R.; Mousavi, S.M.; Hashemi, S.A. Removal of $\mathrm{Cd}^{2+}$ from aqueous solution using eucalyptus sawdust as a bio-bdsorbent: kinetic and equilibrium studies. J. Environ. Treat. Tech. 2020, 8, 112-118.

14. Saeed, B.; Anwer, H.; Naqvi, S.; Siddiqui, A.; Hashim, S. Biosorption of hexavalent chromium metal ions from an aqueous solution of leaves and bark of Cinnamomum verum via green route. SN Appl. Sci. 2020, 2, 526, 1-14, https://doi.org/10.1007/s42452-020-2334-y.

15. Liu, C.; Luan, P.; Li, Q.; Cheng, Z.; Xiang, P.; Liu, D.; Hou, Y.; Yang, Y.; Zhu, H. Biopolymers derived from trees as sustainable multifunctional materials: a review. Adv. Mater. 2020, 2001654, 1-27.

16. Sen, A.; Pereira, H.; Olivella, M.A.; Villaescusa, I. Heavy metals removal in aqueous environments using bark as a biosorbent. Int. J. Environ. Sci. Technol. 2015, 12, 391-404, https://doi.org/10.1007/s13762-0140525-z.

17. Nurnabi, M.; Bhowmik, S.; Rahman, M.S.; Choudhury, T.R.; Parsons, A.J.; Young, S.D. Modification and application of Albizia lebbeck sawdust for the sorption of lead(II) and copper(II) from aqueous solutions. Oriental J. Chem. 2020, 36, 591-600.

18. Alekseeva, A.A.; Fazullin, D.D.; Kharlyamov, D.A.; Mavrin, G.V.; Shaikhiev, I.G.; Stepanova, S.V.; Shaimardanova, A.S. The use of leaves of different tree species as a sorption material for extraction of heavy metal ions from aqueous media. Int. J. Pharm. Technol. 2016, 8, 14375-14391, https://dspace.kpfu.ru/xmlui/handle/net/145648.

19. Abed, F.; Louhab, K.; Abai, N.; Babakhouya, N. Study of the adsorption of methylene blue by natural materials (olive stone, date pit and their mixture) in fixed bed column. Algerian J. Env. Sci. Technol. 2019, 5, 947-954.

20. Banerjee, K. Bioadsorbents as green solution to remove heavy metals from waste water-Review. Int. J. Adv. Sci. Eng. 2020, 6, 43-45.

21. Sverguzova, S.V.; Shaikhiev, I.G.; Fomina, E.V.; Galimova, R.Z. Use of chestnut sheel (Castánea) as adsorption material for removing pollutants from natural and sewage waters: a review. IOP Conf. Series: Mater. Sci. Eng. 2020, 945, 012072, 1-8, https://doi.org/10.1088/1757-899X/945/1/012072.

22. Shaikhiev, I.G.; Sverguzova, S.V.; Shaykhieva, K.I.; Sapronova, Zh.A. The use of walnut shells (Juglans regia) as sorption materials to remove pollutants from natural and waste waters. Chemistry of plant materials. 2020, 2, 5-18, https://doi.org/10.14258/jcprm.2020025622.

23. Lim, T.K. Edible medicinal and non-medicinal plants: volume 4, Fruits. Springer Science+Business Media B.V. 2012, 480-491, https://doi.org/10.1007/978-94-007-4053-2_55. 
24. Prgomet, I., Gonçalves, B., Domínguez-Perles, R., Pascual-Seva, N., Barros, A.I.R.N.A. Valorization challenges to almond residues: phytochemical composition and functional application. Molecules. 2017, 22, 1774, 1-27, https://doi.org/10.3390/molecules22101774.

25. Almond. Available online: https://en.wikipedia.org/wiki/Almond.

26. Jafari, S., Alizadeh, A.I. Nutritive value of different varieties of almond (Prunus dulcis) hulls. Res. Opin. Anim. Vet. Sci. 2011, 1, 734-738.

27. Gradziel, T.M. Almond (Prunus dulcis) breeding. In Breeding Plantation Tree Crops: Temperate Species; Jain, S.M., Priyadarshan, P.M., Eds.; Springer: New York, NY, USA, 2009, 1-31.

28. Homedes, J.M.; Roura, E.; Keim, N.L.; Brown, D. Almond hulls in swine diet reduce diet fat. Calif. Agric. 1993, 47, 27-28.

29. Ledbetter, C.A. Shell cracking strength in almond (Prunus dulcis [Mill.] D.A.Webb.) and its implication in uses as a value-added product. Bioresour. Technol. 2008, 99, 5567-5573.

30. Elahi, M.Y.; Kargar, H.; Dindarlou, M.S.; Kholif, A.E.; Elghandour, M.M.Y.; Rojas-Hernandez, S.; Odongo, N.E.; Salem, A.Z.M. The chemical composition and in vitro digestibility evaluation of almond tree (Prunus dulcis D. A. Webb syn. Prunus amygdalus; var. Shokoufeh) leaves versus hulls and green versus dry leaves as feed for ruminants. Agroforest Syst. 2016, 90, 1-10, https://doi.org/10.1007/s10457-016-9964-5.

31. Quesada, L.; Pérez, A.; Calero, M.; Blázquez, G.; Martín-Lara, M.A. Reaction schemes for estimating kinetic parameters of thermal decomposition of native and metal-loaded almond shell. Process Safety Environ. Protect. 2018, 118, 234-244, https://doi.org/10.1016/j.psep.2018.06.041.

32. De Peters, E.J.; Swanson, K.L.; Bill, H.M.; Asmus, J.; Heguy J.M. Nutritional composition of almond hulls. App. Animal Sci. 2020, 36, 761-770, https://doi.org/10.15232/aas.2020-02035.

33. de Hoyos-Martínez, P.L.; Erdocia, X.; Bouhtoury, F.C.; Prado, R.; Labidi, J. Multistage treatment of almonds waste biomass: Characterization and assessment of the potential applications of raw material and products. Waste Manag. 2018, 80, 40-50, https://doi.org/10.1016/j.wasman.2018.08.051.

34. Ramos, M.; Dominici, F.; Luzi, F.; Jiménez, A.; Garrigós, M.C.; Torre, L.; Puglia, D. Effect of almond shell waste on physicochemical properties of polyester-based biocomposites. Polymers. 2020, 12, 835; 1-17, https://doi.org/10.3390/polym12040835.

35. Ferrandez-Villena, M.; Ferrandez-Garcia, C.E.; Ortuño, T.G.; Ferrandez-Garcia, A.; Ferrandez-Garcia, M.T. Study of the utilisation of almond residues for low-cost panels. Agronomy. 2019, 9, 811, 1-10, https://doi.org/10.3390/agronomy9120811.

36. Modica, A.; Rosselli, S.; Catinella, G.; Sottile, F.; Catania, A. C.; Cavallaro, G.; Lazzara, G.; Botta, L.; Spinella, A.; Bruno M. Solid state 13C-NMR methodology for the cellulose composition studies of the shells of Prunus dulcis and their derived cellulosic materials. Carbohydr. Polym. 2020, 240, 116290, 1-8, https://doi.org/10.1016/j.carbpol.2020.116290.

37. Grioui, N.; Halouani, K.; Agblevor, F.A. Bio-oil from pyrolysis of Tunisian almond shell: Comparative study and investigation of aging effect during long storage. Energy Sustain. Develop. 2014, 21, 100-112, http://dx.doi.org/10.1016/j.esd.2014.05.006.

38. Chen, P.; Cheng, Y.; Deng, S.; Lin, X.; Huang, G.; Ruan, R. Utilization of almond residues. Int. J. Agric. Biol. Eng. 2010, 3, 1-18.

39. Akubude, V.C.; Nwaigwe, K.N. Economic importance of edible and non-edible almond fruit as bioenergy material: A review. American J. Energy Sci. 2016, 3, 31-39.

40. Ismal, O.E.; Ozdogan, E.; Yildirim, L. An alternative natural dye, almond shell waste: effects of plasma and mordants on dyeing properties. Color. Technol. 2013, 129, 431-437, https://doi.org/10.1111/cote.12047.

41. Esfahlan, A.J.; Jamei, R.; Esfahlan, R.J. The importance of almond (Prunus amygdalus L.) and its byproducts. Food Chem. 2010, 120, 349-360, https://doi.org/10.1016/j.foodchem.2009.09.063.

42. Huang, G.; Lapsley, K. Almonds. In Integrated Processing Technologies for Food and Agricultural ByProducts. 2019, 373-390, https://doi.org/10.1016/B978-0-12-814138-0.00015-0.

43. Pal, S.; Lgaz, H.; Tiwari, P.; Chung, I.; Ji, G.; Prakash, R. Experimental and theoretical investigation of aqueous and methanolic extracts of Prunus dulcis peels as green corrosion inhibitors of mild steel in aggressive chloride media. J. Molec. Liq. 2019, 276, 347-361, https://doi.org/10.1016/j.molliq.2018.11.099.

44. Ahmadpour, A.; Tahmasbi, M.; Bastami, T.R.; Besharati, J.A. Rapid removal of cobalt ion from aqueous solutions by almond green hull. J. Hazard. Mater. 2009, 166, 925-930, https://doi.org/10.1016/j.jhazmat.2008.11.103.

45. Pehlivan, E.; Altun, T. Biosorption of chromium(VI) ion from aqueous solutions using walnut, hazelnut and almond shell. J. Hazard. Mater. 2008, 155, 378-384, https://doi.org/10.1016/j.jhazmat.2007.11.071. 
46. Khazaei, I.; Aliabadi, M.; Mosavian, H.T.H. Use of agricultural waste for removal of $\mathrm{Cr}(\mathrm{VI})$ from aqueous solution. Iranian J. Chem. Eng. 2011, 8, 11-23.

47. Dakiky, M.; Khamis, M.; Manassra, A.; Mer'eb, M. Selective adsorption of chromium VI in industrial wastewater using low-cost abundantly available adsorbents. Adv. Environ. Res. 2002, 6, 533-540.

48. Calero, M.; Hernainz, F.; Blazquez, G.; Dionisio, E.; Martin-Lara, M.A. Evaluación de la biosorción de cobre con cáscara de almendra. Afinidad LXVIII, 2011, 554, 274-284.

49. Ruiz, E.D. Aprovechamiento de residuos vegetales para la eliminacion de cobre preserte en medios acuosos mediante biosorcion. Tesis doctoral. Granada, Universidad de Granada. 2012. 409.

50. Aber, S.; Salari, D.; Feiz, B.A. The sorption of copper on almond shell: optimization and kinetics. Water Sci. Technol. 2011, 63, 1389-1395, https://doi.org/10.2166/wst.2011.299.

51. Altun, T.; Pehlivan, E. Removal of copper(II) ions from aqueous solutions by walnut-, hazelnut- and almondshells. Clean. 2007, 35, 601-606, https://doi.org/10.1002/clen.200700046.

52. Yildiz, S. Kinetic and isotherm analysis of $\mathrm{Cu}(\mathrm{II})$ adsorption onto almond shell (Prunus dulcis). Ecol. Chem. Eng. Sci. 2017, 24, 87-106, https://doi.org/10.1515/eces-2017-0007.

53. Maaloul, N.; Oulego, P.; Rendueles, M.; Ghorbal, A.; Díaz, M. Novel biosorbents from almond shells: Characterization and adsorption properties modeling for $\mathrm{Cu}(\mathrm{II})$ ions from aqueous solutions. J. Environ. Chem. Eng. 2017, 5, 2944-2954, http://dx.doi.org/10.1016/j.jece.2017.05.037.

54. Maaloul, N.; Oulego, P.; Rendueles, M.; Ghorbal, A.; Díaz, M. Easy and Cost Effective Preparation of Cellulose Beads from Almond Shell: Characterization and Application in Copper (II) Adsorption from Aqueous Solutions. In Euro-Mediterranean Conference for Environmental Integration 2017, 175-177.

55. Banerjee, M.; Basu, R.K.; Das, S.K. Cu(II) removal using green adsorbents: kinetic modeling and plant scaleup design. Environ. Sci. Pollut. Res. 2018, 1-16, https://doi.org/10.1007/s11356-018-1930-5.

56. de Hoces, M.C.; García, G.B.; Gálvez, A.R.; Álvarez, A.E.; Martín-Lara, M.A. Biosorption of $\mathrm{Cu}^{2+}$ in a packed bed column by almond shell: optimization of process variables. Desalinat. Water Treat. 2013, 51, 1954-1965, https://doi.org/10.1080/19443994.2012.715167.

57. Taha, A.A.; Moustafa, A.H.E.; Abdel-Rahman, H.H.; El-Hameed, M.M.A.A. Comparative biosorption study of $\mathrm{Hg}$ (II) using raw and chemically activated almond shell. Adsorption Sci. Technol. 2018, 36, 521-548, https://doi.org/10.1177/0263617417705473.

58. Khaloo, S.S.; Matin, A.H.; Sharifi, S.; Fadaeinia, M.; Kazempour, N.; Mirzadeh, S. Equilibrium, kinetic and thermodynamic studies of mercury adsorption on almond shell. Water Sci. Technol. 2012, 65, 1341-1349, https://doi.org/10.2166/wst.2012.767.

59. Pehlivan, E.; Altun, T.; Cetin, S.; Bhanger, M.I. Lead sorption by waste biomass of hazelnut and almond shell. J. Hazard. Mater. 2009, 167, 1203-1208, https://doi.org/10.1016/j.jhazmat.2009.01.126.

60. Nasseh, N.; Nasseh, I.; Khodadadi, M.; Beirami, A.; Kamranifar, M. The removal of lead from aqueous solution using almond green hull (Prunus amygdalus-Fascionello) waste material magnetized with $\mathrm{Fe}_{3} \mathrm{O}_{4}$. Ann. Mil. Health Sci. Res. 2017, 15, e66336, 1-7, https://doi.org/10.5812/amh.66336.

61. Brás, I.; Figueirinha, A.; Esteves, B.; Cruz-Lopes, L.P. Valorization of lignocellulosic wastes - evaluation of its toxicity when used in adsorption systems. Int. J. Environ. Ecol. Eng. 2014, 8, 450-454.

62. Coruh, S.; Geyikci, F.; Kilıc, E.; Coruh, U. The use of NARX neural network for modeling of adsorption of zinc ions using activated almond shell as a potential biosorbent. Biores. Tech. 2014, 151, 406-410, http://dx.doi.org/10.1016/j.biortech.2013.10.019.

63. Mehrasbi, M.R.; Farahmandkia, Z.; Taghibeigloo, B.; Taromi, A. Adsorption of lead and cadmium from aqueous solution by using almond shells. Water Air Soil Pollut. 2009, 199, 343-351, http://dx.doi.org/10.1007/s11270-008-9883-9.

64. Cataldo, S.; Gianguzza, A.; Milea, D.; Muratore, N.; Pettignano, A.; Sammartano, S. A critical approach to the toxic metal ion removal by hazelnut and almond shells. Environ. Sci. Pollut. Res. 2018, 25, 4238-4253, https://doi.org/10.1007/s11356-017-0779-3.

65. Bulut, Y.; Tez, Z. Adsorption studies on ground shells of hazelnut and almond. J. Hazard. Mater. 2007, 149, 35-41, https://doi.org/10.1016/j.jhazmat.2007.03.044.

66. Dwivedi, N.; Balomajumder, C.; Mondal, P. Studies of kinetic and equilibrium isotherm models for the sorption of cyanide ion on to almond shell. Res. J. Chem. Sci. 2014, 4, 20-24.

67. Dwivedi, N.; Balomajumder, C.; Mondal, P. Study for the treatment of cyanide bearing wastewater using bioadsorbent Prunus Amygdalus (almond shell): Effect of $\mathrm{pH}$, adsorbent dose, contact time, temperature, and initial cyanide concentration. Int. Res. J. Environ. Sci. 2014, 3, 23-30. 
68. Dwivedi, N.; Balomajumder, C.; Mondal, P. Comparative investigation on the removal of cyanide from aqueous solution using two different bioadsorbents. Water Res. Ind. 2016, 15, 28-40, http://dx.doi.org/10.1016/j.wri.2016.06.002.

69. Adegoke, K.A.; Bello, O.S. Dye sequestration using agricultural wastes as adsorbents. Water Res. Ind. 2015, 12, 8-24, http://dx.doi.org/10.1016/j.wri.2015.09.002.

70. Tripathi, N. Cationic and anionic dye adsorption by agricultural solid wastes: A comprehensive review. IOSR J. App. Chem. 2013, 5, 91-108.

71. Rangabhashiyam, S.; Anu, N.; Selvaraju, N. Sequestration of dye from textile industry wastewater using agricultural waste products as adsorbents. J. Environ. Chem. Eng. 2013, 1, 629-641, http://dx.doi.org/10.1016/j.jece.2013.07.014.

72. Bulgariu, L.; Escudero, L.B.; Bello, O.S.; Iqbal, M.; Nisar, J.; Adegoke, K.A.; Alakhras, F.; Kornaros, M.; Anastopoulos, I. The utilization of leaf-based adsorbents for dyes removal: A review. J. Molec. Liq. 2019, 276, 728-747, https://doi.org/10.1016/j.molliq.2018.12.001.

73. Dardouri, S.; Sghaier, J. A comparative study of adsorption and regeneration with different agricultural wastes as adsorbents for the removal of methylene blue from aqueous solution. Chinese J. Chem. Eng. 2017, 25, 1282-1287, http://dx.doi.org/10.1016/j.cjche.2017.01.012.

74. Deniz, F. Adsorption properties of low-cost biomaterial derived from Prunus amygdalus L. for dye removal from water. Sci. World J. 2013, ID 961671, 1-8, http://dx.doi.org/10.1155/2013/961671.

75. Deniz, F. Dye removal by almond shell residues: Studies on biosorption performance and process design. Mater. Sci. Eng. C. 2013, 33, 2821-2826, http://dx.doi.org/10.1016/j.msec.2013.03.009.

76. Deniz, F. Optimization of methyl orange bioremoval by Prunus amygdalus L. (almond) shell waste: Taguchi methodology approach and biosorption system design. Desalin. Water Treat. 2013, 51, 7067-7073, http://dx.doi.org/10.1080/19443994.2013.767754.

77. Atmani, F.; Bensmaili, A.; Amrane, A. Methyl orange removal from aqueous solutions by natural and treated skin almonds. Desalin. Water Treat. 2010, 22, 174-181, https://doi.org/10.5004/dwt.2010.1425.

78. Hashemian, S.; Shayegan, J. A comparative study of cellulose agricultural wastes (almond shell, pistachio shell, walnut shell, tea waste and orange peel) for adsorption of Violet B dye from aqueous solutions. Orient. J. Chem. 2014, 30, 2091-2098, http://dx.doi.org/10.13005/ojc/300478.

79. Saeed, K.; Ishaq, M.; Sultan, S.; Ahmad, I. Removal of methyl violet 2-B from aqueous solutions using untreated and magnetite-impregnated almond shell as adsorbents. Desalin. Water Treat. 2016, 57, 1348413493, https://doi.org/10.1080/19443994.2015.1058191.

80. Ishaq, M.; Javed, F.; Amad, I.; Ullah, H.; Hadi, F.; Sultan, S. Adsorption of Crystal violet dye from aqueous solutions onto low-cost untreated and $\mathrm{NaOH}$ treated almond shell. Iran. J. Chem. Chem. Eng. 2016, 35, 97106.

81. Senturk, H.B.; Ozdes, D.; Duran, C. Biosorption of Rhodamine 6G from aqueous solutions onto almond shell (Prunus dulcis) as a low cost biosorbent. Desalin. 2010, 252, 81-87, http://dx.doi.org/10.1016/j.desal.2009.10.021.

82. Aliabadi, M.; Khazaei, I.; Hajiabadi, M.; Fazel, S. Removal of Rhodamine B from aqueous solution by almond shell biosorbent. J. Biodiver. Environ. Sci. 2012, 2, 39-44.

83. Ardejani, F.D.; Badii, Kh.; Limaee, N.Y.; Shafaei, S.Z.; Mirhabibi, A.R. Adsorption of Direct Red 80 dye from aqueous solution onto almond shells: Effect of $\mathrm{pH}$, initial concentration and shell type. J. Hazard. Mater. 2008, 151, 730-737, http://dx.doi.org/10.1016/j.jhazmat.2007.06.048.

84. Ozdes, D.; Gundogdu, A.; Duran, C.; Senturk, H.B. Evaluation of adsorption characteristics of Malachite green onto almond shell (Prunus dulcis). Separ. Sci. Technol. 2010, 45, 2076-2085, http://dx.doi.org/10.1080/01496395.2010.504479.

85. Fathi, M.R.; Asfaram, A.; Hadipour, A.; Roosta, M. Kinetics and thermodynamic studies for removal of Acid blue 129 from aqueous solution by almond shell. J. Environ. Health Sci. Eng. 2014, 12, 1-7.

86. Zhou, Y.; Zhang, L.; Cheng, Z. Removal of organic pollutants from aqueous solution using agricultural wastes: A review. J. Molec. Liquids. 2015, 212, 739-762, http://dx.doi.org/10.1016/j.molliq.2015.10.023.

87. Zolgharnein, J.; Shahmoradi, A.; Ghasemi, J. Pesticides removal using conventional and low-cost adsorbents: A review. Clean - Soil, Air, Water. 2011, 39, 1105-1119.

88. Okasha, A.Y.; Ibrahim, H.G. Phenol removal from aqueous systems by sorption of using some local waste materials. EJEAFChe. 2010, 9, 796-807. 
89. Antunes, M.C.G.; Pinto, S.; Braga, F.G.; Silva, J.C.G.E. Optimisation of bisphenol A removal from water using chemically modified pine bark and almond shell. Chem. Ecol. 2012, 28, 141-152, http://dx.doi.org/10.1080/02757540.2011.638629.

90. Cornélio, D.J.M. Processos alternativos de remoção de poluentes orgânicos prioritários. Tese de mestrado, Universidado de Porto, Portugal, 2008. 86.

91. Estevinho, B.N.; Ratola, N.; Alves, A.; Santos, L. Pentachlorophenol removal from aqueous matrices by sorption with almond shell residues. J. Hazard. Mater. 2006, B137, 1175-1181, http://dx.doi.org/10.1016/j.jhazmat.2006.04.001.

92. Estevinho, B.N.; Ribeiro, E.; Alves, A.; Santos, L. A preliminary feasibility study for pentachlorophenol column sorption by almond shell residues. Chem. Eng. J. 2008, 136, 188-194, http://dx.doi.org/10.1016/j.cej.2007.03.081.

93. Braga, F.G.; Pinto, S.; Antunes, M.C.G. Comparative study of $17 \beta$-estradiol removal from aqueous solutions using pine bark and almond shell as adsorbents. Microchim Acta. 2011, 173, 111-117, http://dx.doi.org/10.1007/s00604-010-0531-x.

94. Hosseini, S.; Malekbala, M.R.; Hosseini, S.; Babadi, F.E.; Balavandy, S.K.; Shavandi, M.A. Biosorption of azoimide on almond integument: Kinetics, isotherm and thermodynamics studies. J. Environ. Chem. Eng. 2013, 1, 696-702, http://dx.doi.org/10.1016/j.jece.2013.07.007.

95. Nabais, J.M.V.; Laginhas, C.E.C.; Carrott, P.J.M.; Carrott, M.M.L.R. Production of activated carbons from almond shell. Fuel Proces. Technol. 2011, 92, 234-240, http://dx.doi.org/10.1016/j.fuproc.2010.03.024.

96. Toles, C.A.; Marshall, W.E.; Johns, M.M.; Wartelle, L.H.; McAloon, A. Acid-activated carbons from almond shells: physical, chemical and adsorptive properties and estimated cost of production. Biores. Technol. 2000, $71,87-92$.

97. Omri, A.; Benzina, M. Adsorption characteristics of silver ions onto activated carbon prepared from almond shell. Desalin. Water Treat. 2013, 51, 2317-2326, https://doi.org/10.1080/19443994.2012.734585.

98. Saeedi, M.; Jamshidi, A.; Abessi, O.; Bayat, J. Removal of dissolved cadmium by adsorption anto walnut and almond shell charcoal: Comparison with granular activated carbon (GAC). J. Water Wastewater. 2009, 70, 16-22.

99. Demirbas, E.; Kobya, M.; Konukman, A.E.S. Error analysis of equilibrium studies for the almond shell activated carbon adsorption of $\mathrm{Cr}(\mathrm{VI})$ from aqueous solutions. J. Hazard. Mater. 2008, 154, 787-794, http://dx.doi.org/10.1016/j.jhazmat.2007.10.094.

100.Nasseh, N.; Taghavi, L.; Barikbin, B.; Khodadadi, M. Advantage of almond green hull over its resultant ash for chromium(VI) removal from aqueous solutions. Int. J. Environ. Sci. Technol. 2017, 14, 251-262, http://dx.doi.org/10.1007/s13762-016-1210-1.

101.Kazemipour, M.; Ansari, M.; Tajrobehkar, S.; Majdzadeh, M.; Kermani, H.R. Removal of lead, cadmium, zinc, and copper from industrial wastewater by carbon developed from walnut, hazelnut, almond, pistachio shell, and apricot stone. J. Hazard. Mater. 2008, 150, 322-327, http://dx.doi.org/10.1016/j.jhazmat.2007.04.118.

102.Zbair, M.; Anfar, Z.; Ahsaine, H.A.; El Alem, N.; Ezahri, M. Acridine orange adsorption by zinc oxide/almond shell activated carbon composite: Operational factors, mechanism and performance optimization using central composite design and surface modeling. J. Environ. Manag. 2018, 206, 383-397, https://doi.org/10.1016/j.jenvman.2017.10.058.

103.Hosseini, S.; Soltani, S.M.; Jahangirian, H.; Babadi, F.E.; Choong, T.S.Y.; Khodapanah, N. Fabrication and characterization porous carbon rod-shaped from almond natural fibers for environmental applications. $J$. Environ. Chem. Eng. 2015, 3, 2273-2280, http://dx.doi.org/10.1016/j.jece.2015.08.027.

104.Hashemian, S.; Salari, K.; Yazdi, Z.A. Preparation of activated carbon from agricultural wastes (almond shell and orange peel) for adsorption of 2-pic from aqueous solution. J. Ind. Eng. Chem. 2014, 20, 1892-1900, http://dx.doi.org/10.1016/j.jiec.2013.09.009.

105.Mohan, D.; Sarswat, A.; Singh, V.K.; Alexandre-Franco, M.; Pittman Jr. C.U. Development of magnetic activated carbon from almond shells for trinitrophenol removal from water. Chem. Eng. J. 2011, 172, 11111125, http://dx.doi.org/10.1016/j.cej.2011.06.054.

106.Homem, V.; Alves, A.; Santos, L. Amoxicillin removal from aqueous matrices by sorption with almond shell ashes. Int. J. Environ. Anal. Chem. 2010, 90, 1063-1084, http://dx.doi.org/10.1080/03067310903410964. 